Note

\title{
Effects of Parabens and Isothiazolinone on the Microbiological Quality of Baby Shampoo: The Challenge Test
}

\author{
SLIM SMAOUI ${ }^{\neq, 1, *}$, AND HAJER BEN HLIMA ${ }^{\neq, 1}$ \\ ${ }^{1}$ Laboratory of Microorganisms and Biomolecules, Centre of Biotechnology of Sfax, \\ Road of Sidi Mansour Km 6, P.O. Box 1177, 3018 Sfax, Tunisia \\ Received 24 October, 2011/Accepted 28 March, 2012
}

\begin{abstract}
An in vitro microbial challenge test has been developed to predict the likelihood of consumer contamination of baby shampoo. Four preservatives were tested in our study: the parbens Medcide D, Medcide PB, Sepicide HB. and isothiazolinone Methylisothiazolinone/ Chloromethylisothiazolinone $[\mathrm{MI} / \mathrm{MCl}$. These preservatives were tested separately and in combination. The challenge test involved inoculating the product with Micrococcus luteus, Staphylococcus aureus, Escherichia coli, Salmonella enterica, Pseudomonas aeruginosa, Aspergillus brasiliensis and Candida albicans. Inhibition growth of these microorganisms at each preservative concentration was followed over a $28 \mathrm{~d}$ period. The test was used to classify products as poorly preserved, marginally preserved, or well-preserved. Interestingly, it was the combination $(0.1 \%$ Isothiazolinone $[\mathrm{MI} / \mathrm{MCl}]$ and $0.1 \%$ Sepicide $\mathrm{HB}$ ) which inhibited most the microbial growth of microorganims while preserving the physicochemical properties of the product. As a result, the challenge test described can be accurately used to predict the risk of consumer contamination of cosmetic products.
\end{abstract}

Key words: Baby shampoo/Parabens/Isothiazolinone [MI/MCl]/Challenge test/Microbial growth.

Cosmetics are occasionally contaminated with spoilage microorganisms, and the biggest concern regarding contamination is the possible presence of pathogens that may pose health threats (Cowen and Steiger, 1976). In cosmetics, contaminating microorganisms may cause spoilage of the product and present a serious health risk for consumers worldwide (Becks and Lorenzoni, 1995; Behravan et al., 2005). Even non- pathogenic spoilage microbes in a cosmetic may cause disease under certain conditions. For example, a microbe contaminating a cosmetic product may be invasive if the cosmetic is applied to cover a blemish or break in the skin (FDA, 2001). The microbiologist uses a variety of chemical preservatives to prevent contamination by pathogens or

\footnotetext{
* Corresponding author. Tel/Fax: 0021674870451 ; E-mail:slim.smaoui(a) yahoo. fr

* These authors have contributed equally to the present study.
}

spoilage microorganisms, and their use can extend the shelf life of the products. The preservatives include benzyl alcohol, boric acid, sorbic acid, chlorhexidine, formaldehyde, parabens, quaternary ammonium compounds, phenol, imidazolidinyl compounds, and others. Several excellent reviews cover this topic (Durant and Higdon, 1991; Chapman, 1987).

Parabens are the most widely used preservatives in commercially available shampoos (Fox, 1988). The most common parabens used in cosmetic products are methylparaben, propylparaben, and butylparaben. Fox (1988) reported that propylparaben is most commonly used as an antimicrobial in water-based products such as cosmetics, shampoos, moisturizers, conditioners and sunscreens. Typically, more than one paraben is used in a product, and they are often used in combination with other types of preservatives to work against a broad range of microorganisms. The combined use of parabens and other 
preservatives could reduce microbial levels while increasing the shelf life of products. Among these preservatives, the most frequently used is isothiazolinone: Methylisothiazolinone / Chloromethylisothiazolinone $[\mathrm{Ml} / \mathrm{MCl}]$. $\mathrm{Ml}$ is used as a co-biocide with $\mathrm{MCl}$ and has been recently introduced as a stand-alone preservative. Activities of organic acids are profoundly compromised in neutral and alkaline formulations as isthe stability of isothiazolinone preservatives in the presence of amines (Collier et al., 1990).

Assessment of the preservative efficacy in cosmetics is usually performed using the challenge test (ISO/WD 11930, 2008). This test provides assurance regarding the microbiological levels of the product at the time the test is performed. Russell (2003) suggested that challenge test should be undertaken at the beginning, during and at the end of the shelf life of the product.

Test-challenging a product with appropriate organisms is a major concern in determining how effective a preservative must be, and is based on the inoculation of the cosmetic product with bacteria, followed by incubation and sampling for survivors during the storage period (Russell, 2003).

Considering the promising properties of additives and the growing interest in their efficient use, this study postulates that parabens (Medcide D, Medicide $\mathrm{PB}$ and Sepicide $\mathrm{HB}$ ) and isothiazolinone [MI/MCl] which are naturally abundant and available may represent efficient additives. These agents could replace the commonly used expensive preservatives and improve the cost-effectiveness of the overall production process, and hence, the final end product. Accordingly, this study used the challenge test to focus on the value of adding parabens and isothiazolinone $[\mathrm{Ml} / \mathrm{MCl}]$ to baby shampoo separately and in combination at various concentrations.

The baby shampoo used in this study was prepared by the manufacturer (Parfumerie Africa) in a well-defined form. The shampoo consisted of the following: (1) water, (2) anionic surfactants Zetesol MGS (magnesium lauryl-2 sulfate) and Texapon N70, the non-ionic surfactant Purtan CFD (cocamide diethanoiamide) and the amphoteric surfactant sabosol PB (cocamidopropyl Betain) [all surfactants were provided by Zschimmer \& Schwarz Italiana S.p.A], (3) Polyquaternium 10 (Chematek S.p.A), a detangling agent, (4) Crovol Maracuja, PEG-60 Maracuja Glycerides (Croda Chemical Europe, England), an anti-irritating agent, (5) EDTA (SigmaAldrich, USA), a chelating agent, (6) Triethanolamine (Virginia Dare Extract Co., Inc., USA), a pH regulator, and (7) Linalool (Simagchem Corporation, China)
In our study, four types of preservatives were tested. First was Medcide D (MD), a mixture of (diazolidinyl urea) and methyl and propyl parabens in propylene glycol (Medolla Italia, Italy). It is a clear liquid and can be easily incorporated in cosmetic formulations at any stage of the formulating process. This preservative is effective in a wide range of $\mathrm{pH}$ and suitable for cold formulations of shampoos. It is used at concentrations from 0.5 to $1.0 \%$ in preparations. The second preservative was Medcide PB (MPB) which consists of a selected combination of methyl, ethyl, butyl, propyl and isobutyl parabens in phenoxyethanol (Medolla Italia, Italy). It is a clear liquid and added into end products at temperatures between $0^{\circ} \mathrm{C}$ and $40^{\circ} \mathrm{C}$. pH tolerance is given for an acidic and neutral environment. It is used at concentrations from 0.3 to $1.0 \%$ in preparations. Another preservative used in this study was Sepicide HB (SHB), a mixture of methyl, ethyl and propylparaben in phenoxyethanol (Seppic, France). This is a slightly colored viscous liquid, slightly soluble in water. It is used at concentrations from 0.5 to $1.5 \%$ in preparations. The final preservative used was Isothiazolinone (Chloromethylisothiazolinone/Methylisothiazolinone) $(\mathrm{Ml} / \mathrm{MCl})$, an electrophilic preservative mixture. It is a slightly yellow liquid, soluble in water and used when the product $\mathrm{pH}$ is between 3 and 8 . It was used in concentrations at $0.01-0.1 \%$ (Simagchem Corporation, China).

Firstly, these preservatives were added separately to the baby shampoo at 1.0\% MD; $1 \%$ MPB; $1.5 \%$ $\mathrm{SHB}$ and $0.1 \%[\mathrm{Ml} / \mathrm{MCl}]$. Thereafter, preservatives were used in combination according to the following concentrations: $0.5 \% \mathrm{MD}+0.5 \% \mathrm{MPB}, 0.5 \% \mathrm{MD}+$ $0.5 \% \mathrm{SHB}, 0.1 \% \mathrm{MD}+0.1 \%[\mathrm{Ml} / \mathrm{MCl}], 0.5 \% \mathrm{MPB}+$ $0.5 \% \mathrm{SHB}, 0.1 \% \mathrm{MPB}+0.1 \%[\mathrm{MI} / \mathrm{MCl}]$ and $0.1 \%$ $\mathrm{SHB}$ and $0.1 \%[\mathrm{MI} / \mathrm{MCl}$. A baby shampoo sample without any additives was used as the control.

For the microbial challenge test, each of the test formulations was inoculated with each of the following microorganisms: Micrococcus luteus LB 14110, Staphylococcus aureus ATCC 6538, Escherichia coli ATCC 8739, Salmonella enterica ATCC 43972, Pseudomonas aeruginosa ATCC 9027, Aspergillus brasiliensis ATCC16404 and Candida albicans ATCC 10231, using the test procedure modified from United States Pharmacopeia (USP, 1994). Microorganisms were grown in aerobic conditions. S. enterica ATCC 43972, P. aeruginosa ATCC 9027 and M. luteus LB 14110 were grown $24 \mathrm{~h}$ at $30^{\circ} \mathrm{C}$ in Luria Bertani medium LB (10 g// peptone; $5 \mathrm{~g} / / \mathrm{NaCl} ; 5 \mathrm{~g} / /$ yeast extract; $\mathrm{pH}$ 7.2) while E. coli ATCC 8739 and S. aureus ATCC 6538 were grown at $37^{\circ} \mathrm{C}$ on the same medium (LB). Yeast and fungal strains were cultivated on 
sabouraud dextrose agar (Difco Laboratories) at 25 ${ }^{\circ} \mathrm{C}$ for $48 \mathrm{~h}$ and $1 \mathrm{wk}$, respectively. All microorganisms were harvested by washing the cells from the slants with sterile saline. The growth in terms of colony forming units per milliliter (CFU/ml) of each organism was determined. Twenty $\mathrm{ml}$ samples were placed into sterile glass bottles, one for each organism and inoculated with the test microorganism $\left(10^{5}-10^{6}\right.$ colonies or spores $/ \mathrm{ml}$ sample). The containers were incubated at room temperature $\left(35^{\circ} \mathrm{C}\right)$ for a total of $28 \mathrm{~d}$ and examined periodically. Examination was done initially and after $3,7,14,21$ and $28 \mathrm{~d}$ of inoculation. Plate counts were performed using media corresponding to those in primary cultivation.

For the stability test at ambient conditions, the formulations prepared were evaluated in terms of their clarity, foam producing ability and fluidity (Aghel et al., 2007) and the $\mathrm{pH}$ of $10 \%$ shampoo solution in distilled water was determined at room temperature $25^{\circ} \mathrm{C}$ (Mainkar and Jolly, 2000). The cylinder shake method was used for determining foaming ability. Fifty $\mathrm{ml}$ of the $1 \%$ shampoo solution was put into a $250 \mathrm{ml}$ graduated cylinder, covered and shaken 10 times. The total volumes of the foam contents after 1 min shaking were recorded. Immediately after shaking, the volume of the foam was calculated each min for 4 min (Klein, 2004). For stability studies, clear liquid shampoos were formulated. The samples in glass containers were stored at room temperature $\left(35^{\circ} \mathrm{C}\right)$ for three months. After the storage, the preservative efficacy was tested. The thermal stability of formulations was studied by placing the samples in glass tubes in a humidity chamber at $45^{\circ} \mathrm{C}$ and $75 \%$ relative humidity. Their appearance and physical stability were inspected each month for a period of three months (Barel et al., 2001).

All measurements were carried out in triplicate, and all microbial counts were converted into base-10 logarithms of colony forming units per $\mathrm{ml}$ of the samples $(\log 10 \mathrm{CFU} / \mathrm{g})$. Data were subjected to analysis of variance (ANOVA) using the General Linear Models procedure of the Statistical Analysis System software of the SAS Institute (SAS, 1990). Differences among the mean values of the various treatments and storage periods were determined by the least significant difference (LSD) test, and the significance was defined at $P<0.05$. The differences equal to or greater than the identified LSD values were considered statistically significant.

For microbiological evaluation, sterility is not necessary but the shampoos must not be contaminated with pathogenic microorganisms and they should not harbour microbial contaminants in high numbers (Ravita et al., 2009). With the aim of evaluating the microbiological effect of additives on baby shampoo, combinations of various parabens (MPB, MD and SHB) and Isothiazolinone $(\mathrm{MI} / \mathrm{MCl})$ were prepared at different concentrations (Table 1). Thus, we studied their capacities to inhibit Gram positive bacteria ( M. Iuteus LB 14110 and S. aureus), Gram negative bacteria (E. coli ATCC 8739, S. enterica ATCC 43972, $P$. aeruginosa ATCC 9027 and moulds ( $C$. albicans ATCC 10231 and $A$. brasiliensis ATCC 16404)

The initial population of $M$. luteus LB 14110 in unpreserved samples was $6 \log _{10} \mathrm{CFU} / \mathrm{ml}$ (Table 2). This population slightly increased until the seventh $d$ reaching $6.9 \log _{10} \mathrm{CFU} / \mathrm{ml}$, then it was decreased to $4.18 \log _{10} \mathrm{CFU} / \mathrm{ml}$ at the end of storage time in nontreated samples (sample 1). Nevertheless, for all treated samples a significant reduction in M. luteus population was observed in comparison with sample 1. For example on the $21^{\text {st }} \mathrm{d}$ of storage, MPB at $1.0 \%$ reduced the number of $M$. luteus to $99.99 \%$. Used alone, MPB was the best preservative among the parabens studied. $0.1 \%[\mathrm{Ml} / \mathrm{MCl}]$ reduced the microbial load of $M$. luteus in treated samples after $14 \mathrm{~d}$ of storage. On the other hand, samples treated with MPB / $[\mathrm{Ml} / \mathrm{MCl}]$ in combination showed delayed growth for $M$. luteus in comparison with controls. A 99.99\% reduction in bacterial cell number $(P<0.01)$ was observed after $3 \mathrm{~d}$ in the tested cosmetic product according to the challenge test (Table 2); similarly, a logarithmic reduction of $5(P<0.01)$ by the $7^{\text {th }} \mathrm{d}$ was noted in the sample treated with SHB / $[\mathrm{Ml} / \mathrm{MCl}]$ combination (Table 2).

Staphylococcus aureus ATCC 6538 is a common skin organism (Geis, 2006). Most preservative challenge test methods use it to examine cosmetic products because it is the most common contaminant that

TABLE 1. Different percentages of preservatives used in formulations

\begin{tabular}{lcccccccccccc}
\hline Preservatives & \multicolumn{10}{c}{ Concentration used in formula No. (\%) } \\
\cline { 2 - 12 } MD & 1 & 2 & 3 & 4 & 5 & 6 & 7 & 8 & 9 & 10 & 11 \\
MPB & - & 1.0 & - & - & - & 0.5 & 0.5 & 0.1 & - & - & - \\
SHB & - & - & 1.0 & - & - & 0.5 & - & - & 0.5 & 0.1 & - \\
{$[\mathrm{MI} / \mathrm{MCl}]$} & - & - & - & 1.5 & - & - & 0.5 & - & 0.5 & - & 0.1 \\
\hline
\end{tabular}


TABLE 2. Effect of preservatives on the microbial load of Gram positive Bacteria: Micrococcus luteus LB 14110 and Staphylococcus aureus ATCC 6538

\begin{tabular}{|c|c|c|c|c|c|c|c|}
\hline \multirow[t]{2}{*}{ Sample $N^{\circ}$} & \multirow{2}{*}{$\begin{array}{l}\text { Microorganisms } \\
\text { (Gram + Bacteria) }\end{array}$} & \multicolumn{6}{|c|}{ Microbial load $\left(\log _{10} \mathrm{CFU} / \mathrm{ml}\right)$} \\
\hline & & Initial & $3 d$ & $7 \mathrm{~d}$ & $14 d$ & $21 d$ & $28 d$ \\
\hline \multirow{2}{*}{1} & M. Iuteus LB 14110 & $6.0^{\mathrm{a}}$ & $6.33 \pm 0.14^{a}$ & $6.9 \pm 0.06^{b}$ & $6.23 \pm 0.10^{\mathrm{a}}$ & $5.96 \pm 0.05^{a}$ & $4.18 \pm 0.08^{\circ}$ \\
\hline & S. aureus ATCC 6538 & $5.7^{\mathrm{a}}$ & $5.61 \pm 0.08^{a}$ & $5.14 \pm 0.07^{a}$ & $4.83 \pm 0.12^{b}$ & $3.12 \pm 0.09^{\circ}$ & $2.31 \pm 0.06^{\circ}$ \\
\hline \multirow{2}{*}{2} & M. Iuteus LB 14110 & $6.0^{a}$ & $5.66 \pm 0.05^{a}$ & $4.01 \pm 0.07^{b}$ & $3.18 \pm 0.09^{b}$ & $1.81 \pm 0.14^{\circ}$ & $<1$ \\
\hline & S. aureus ATCC 6538 & $5.7^{\mathrm{a}}$ & $5.50 \pm 0.04^{a}$ & $3.89 \pm 0.03^{b}$ & $2.68 \pm 0.1^{\circ}$ & $<1$ & $<1$ \\
\hline \multirow{2}{*}{3} & M. Iuteus LB 14110 & $6.0^{\mathrm{a}}$ & $5.32 \pm 0.06^{a}$ & $3.67 \pm 0.03^{b}$ & $1.22 \pm 0.09^{\circ}$ & $<1$ & $<1$ \\
\hline & S. aureus ATCC 6538 & $5.7^{\mathrm{a}}$ & $4.65 \pm 0.04^{a}$ & $2.22 \pm 0.09^{b}$ & $<1$ & $<1$ & $<1$ \\
\hline \multirow{2}{*}{4} & M. Iuteus LB 14110 & $6.0^{\mathrm{a}}$ & $5.44 \pm 0.08^{a}$ & $3.91 \pm 0.03^{b}$ & $2.69 \pm 0.07^{b}$ & 1.11 & $<1$ \\
\hline & S. aureus ATCC 6538 & $5.7^{\mathrm{a}}$ & $4.92 \pm 0.06^{a}$ & $3.77 \pm 0.03^{b}$ & $2.45 \pm 0.04^{b}$ & $<1$ & $<1$ \\
\hline \multirow{2}{*}{5} & M. Iuteus LB 14110 & $6.0^{\mathrm{a}}$ & $4.82 \pm 0.07^{b}$ & $2.28 \pm 0.08^{\circ}$ & $<1$ & $<1$ & $<1$ \\
\hline & S. aureus ATCC 6538 & $5.7^{\mathrm{a}}$ & $3.56 \pm 0.1^{b}$ & $1.82 \pm 0.07^{\circ}$ & $<1$ & $<1$ & $<1$ \\
\hline \multirow{2}{*}{6} & M. Iuteus LB 14110 & $6.0^{a}$ & $3.12 \pm 0.05^{b}$ & $1.67 \pm 0.06^{c}$ & $<1$ & $<1$ & $<1$ \\
\hline & S. aureus ATCC 6538 & $5.7^{\mathrm{a}}$ & $2.22 \pm 0.08^{b}$ & $<1$ & $<1$ & $<1$ & $<1$ \\
\hline \multirow{2}{*}{7} & M. Iuteus LB 14110 & $6.0^{\mathrm{a}}$ & $4.44 \pm 0.07^{b}$ & $2.61 \pm 0.05^{c}$ & $1.43 \pm 0.11^{c}$ & $<1$ & $<1$ \\
\hline & S. aureus ATCC 6538 & $5.7^{\mathrm{a}}$ & $3.92 \pm 0.04^{b}$ & $2.33 \pm 0.08^{c}$ & $<1$ & $<1$ & $<1$ \\
\hline \multirow{2}{*}{8} & M. luteus LB 14110 & $6.0^{a}$ & $3.55 \pm 0.1^{b}$ & $1.18 \pm 0.06^{c}$ & $<1$ & $<1$ & $<1$ \\
\hline & S. aureus ATCC 6538 & $5.7^{\mathrm{a}}$ & $1.26 \pm 0.04^{b}$ & $<1$ & $<1$ & $<1$ & $<1$ \\
\hline \multirow{2}{*}{9} & M. luteus LB 14110 & $6.0^{a}$ & $4.77 \pm 0.07^{b}$ & $2.33 \pm 0.09^{\circ}$ & $1.21 \pm 0.11^{\circ}$ & $<1$ & $<1$ \\
\hline & S. aureus ATCC 6538 & $5.7^{\mathrm{a}}$ & $2.75 \pm 0.13^{b}$ & $1.89 \pm 0.1^{c}$ & $<1$ & $<1$ & $<1$ \\
\hline \multirow{2}{*}{10} & M. Iuteus LB 14110 & $6.0^{a}$ & $<1$ & $<1$ & $<1$ & $<1$ & $<1$ \\
\hline & S. aureus ATCC 6538 & $5.7^{\mathrm{a}}$ & $<1$ & $<1$ & $<1$ & $<1$ & $<1$ \\
\hline \multirow{2}{*}{11} & M. Iuteus LB 14110 & $6.0^{a}$ & $1.42 \pm 0.11^{b}$ & $<1$ & $<1$ & $<1$ & $<1$ \\
\hline & S. aureus ATCC 6538 & $5.7^{\mathrm{a}}$ & $<1$ & $<1$ & $<1$ & $<1$ & $<1$ \\
\hline
\end{tabular}

\pm : Standard deviation of three replicates

a-c: Averages with different letters in the same column are different $(P<0.05)$.

may pose threats to consumers (Cowen and Steiger, 1976). It is used as a representative Gram-positive cocci in many tests. At the same time, since its nutrient needs are comparatively demanding, it does not always seem to be a logical choice as a challenge inoculum.

The initial population of $S$. aureus in samples without preservatives was $5.7 \log _{10} \mathrm{CFU} / \mathrm{ml}$ (Table 2). This value decreased with the storage time reaching $2.31 \log _{10} \mathrm{CFU} / \mathrm{ml}$ on the $28^{\text {th }} \mathrm{d}$ of storage. However, for all the treated samples, the initial load of $S$. aureus decreased rapidly until it was completely eliminated. In fact, after three d of storage, the absence of $S$. aureus was observed in samples treated with MPB / $[\mathrm{Ml} / \mathrm{MCl}]$ and $\mathrm{SHB} /[\mathrm{Ml} / \mathrm{MCl}]$ combinations. Paraben blends with MPB / MD, MPB / SHB and MD / SHB showed a progressive decrease in the CFU values after 7,14 and $28 \mathrm{~d}$ of storage respectively. (Table 2)

Jacobs and Sade have reported in 1984 that methyl paraben at $0.5 \mathrm{mM}$ sensitizes anoxic buffered suspensions of $S$. aureus to gamma radiation by over $150 \%$. During storage, M. luteus and S. aureus counts increased in non-treated samples but it was clear that all treatments resulted in a significant population reduction $(P<0.05)$ in baby shampoo.

E. coli ATCC 8739 is a fermentative Gram-negative rod. It is a member of one of the largest bacterial families, the Enterobacteriaceae, and is considered an indicator of fecal contamination (Geis, 2006). During storage, E. coli counts slightly increased in sample 1 in the 3 first $d$ of storage and then decreased to a final load of $3.33 \log _{10} \mathrm{CFU} / \mathrm{ml}$ but it was clear that all treatments resulted in a significant population reduction even since the first $\mathrm{d}$ of storage $(P$ $<0.05)$. Interestingly, samples treated with the MPB / $[\mathrm{Ml} / \mathrm{MCl}]$ combination delayed significantly the $E$. coli growth in comparison with controls (Table 3 ). In fact, $E$. coli loads were less than $1 \log _{10} \mathrm{CFU} / \mathrm{ml}$ from the $3^{\text {rd }} \mathrm{d}$ of storage. In addition, a reduction of $99.99 \%$ in the number of the microorganisms was observed by the $7^{\text {th }} d$ of challenge for combinations MD / $[\mathrm{Ml} / \mathrm{MCl}]$ and SHB / [Ml/MCl]. A 99.99\% reduction in bacterial cell number $(P<0.01)$ was observed after $14 \mathrm{~d}$ in the tested cosmetic product treated with [Ml/MCl], MD/MPB and MD/SHB.

Maximal reduction of S. Enterica ATCC 43972 
count was shown by the MPB / $[\mathrm{Ml} / \mathrm{MCl}]$ combination, (Table 3) followed by samples treated with MD / [Ml/MCl]. Same inhibition levels were observed for samples treated by the MPB / MD and SHB / $[\mathrm{Ml} / \mathrm{MCl}]$ combinations. By the end of the storage period (day 28), all $S$. enterica counts of samples treated with different combinations were reduced to 99.99\%.

$P$. aeruginosa is a non-fermentative Gram-nega tive rod and a well-known and highly ubiquitous pathogen. It also shows high resistance to many preserva- tives (Geis, 2006). The $P$. aeruginosa challenge test results are shown in Table 3 . The results showed a reduction and an elimination of the pathogen over the $28 \mathrm{~d}$ of the challenge period for the ten preservative concentrations used. On the other hand, $P$. aeruginosa challenge testing showed that the isothiazolinone-preserved formula $[\mathrm{Ml} / \mathrm{MCl}]$ used in combination with parabens rapidly reduced and eliminated the microorganism whereas paraben-preserved shampoo showed elimination of the Pseudomonas load only after 21 and $28 \mathrm{~d}$ of storage (Table 3).

TABLE 3. Effect of preservatives on the microbial load of Gram negative Bacteria: Escherichia coli ATCC 8739, Salmonella Enterica ATCC 43972 and Pseudomonas aeruginosa ATCC 9027

\begin{tabular}{|c|c|c|c|c|c|c|c|}
\hline \multirow[t]{2}{*}{ Sample No. } & \multirow{2}{*}{$\begin{array}{l}\text { Microorganisms } \\
\text { (Gram-Bacteria) }\end{array}$} & \multicolumn{6}{|c|}{ Microbial load $\left(\log _{10} \mathrm{CFU} / \mathrm{ml}\right)$} \\
\hline & & Initial & $3 d$ & $7 d$ & $14 d$ & $21 d$ & $28 d$ \\
\hline \multirow{3}{*}{1} & E. coli ATCC 8739 & $5.4^{\mathrm{a}}$ & $5.76 \pm 0.06^{\mathrm{a}}$ & $5.54 \pm 0.07^{\mathrm{a}}$ & $5.53 \pm 0.09^{a}$ & $4.9 \pm 0.05^{\mathrm{a}}$ & $3.33 \pm 0.04^{b}$ \\
\hline & S. Enterica ATCC 43972 & $5.9^{\mathrm{a}}$ & $6.29 \pm 0.04^{a}$ & $5.64 \pm 0.07^{\mathrm{a}}$ & $4.98 \pm 0.09^{a}$ & $3.3 \pm 0.03^{b}$ & $2.97 \pm 0.1^{b}$ \\
\hline & P. aeruginosa ATCC 9027 & $6.0^{\mathrm{a}}$ & $5.84 \pm 0.07^{\mathrm{a}}$ & $4.88 \pm 0.04^{a}$ & $4.29 \pm 0.08^{b}$ & $3.0 \pm 0.02^{b}$ & $2.28 \pm 0.04^{\circ}$ \\
\hline \multirow{3}{*}{2} & E. coli ATCC 8739 & $5.4^{\mathrm{a}}$ & $5.21 \pm 0.1^{\mathrm{a}}$ & $3.77 \pm 0.12^{b}$ & $2.65 \pm 0.09^{b}$ & $1.43 \pm 0.06^{\circ}$ & $<1$ \\
\hline & S. Enterica ATCC 43972 & $5.9^{\mathrm{a}}$ & $5.70 \pm 0.06^{a}$ & $4.19 \pm 0.04^{b}$ & $2.92 \pm 0.03^{\circ}$ & $1.55 \pm 0.17^{\circ}$ & $<1$ \\
\hline & P. aeruginosa ATCC 9027 & $6.0^{\mathrm{a}}$ & $5.71 \pm 0.14^{a}$ & $4.78 \pm 0.09^{a}$ & $3.68 \pm 0.05^{b}$ & $2.11 \pm 0.04^{\circ}$ & $<1$ \\
\hline \multirow{3}{*}{3} & E. coli ATCC 8739 & $5.4^{\mathrm{a}}$ & $4.41 \pm 0.05^{a}$ & $2.17 \pm 0.08^{b}$ & $1.18 \pm 0.05^{\circ}$ & $<1$ & $<1$ \\
\hline & S. Enterica ATCC 43972 & $5.9^{a}$ & $4.89 \pm 0.03^{a}$ & $2.41 \pm 0.1^{b}$ & $1.31 \pm 0.11^{\circ}$ & $<1$ & $<1$ \\
\hline & P. aeruginosa ATCC 9027 & $6.0^{\mathrm{a}}$ & $5.59 \pm 0.14^{\mathrm{a}}$ & $3.98 \pm 0.12^{b}$ & $3.02 \pm 0.08^{b}$ & $1.76 \pm 0.07^{\circ}$ & $<1$ \\
\hline \multirow{3}{*}{4} & E. coli ATCC 8739 & $5.4^{\mathrm{a}}$ & $4.78 \pm 0.07^{\mathrm{a}}$ & $3.71 \pm 0.04^{b}$ & $2.41 \pm 0.14^{b}$ & $1.4 \pm 0.06^{\circ}$ & $<1$ \\
\hline & S. Enterica ATCC 43972 & $5.9^{a}$ & $5.13 \pm 0.08^{a}$ & $4.07 \pm 0.03^{b}$ & $2.65 \pm 0.08^{\circ}$ & $1.55 \pm 0.05^{\circ}$ & $<1$ \\
\hline & P. aeruginosa ATCC 9027 & $6.0^{a}$ & $5.64 \pm 0.06^{a}$ & $4.24 \pm 0.08^{b}$ & $3.33 \pm 0.03^{b}$ & $2.0 \pm 0.04^{\circ}$ & $<1$ \\
\hline \multirow{3}{*}{5} & E. coli ATCC 8739 & $5.4^{\mathrm{a}}$ & $3.35 \pm 0.05^{b}$ & $1.82 \pm 0.04^{\circ}$ & $<1$ & $<1$ & $<1$ \\
\hline & S. Enterica ATCC 43972 & $5.9^{\mathrm{a}}$ & $3.79 \pm 0.08^{b}$ & $2.03 \pm 0.03^{\circ}$ & $1.23 \pm 0.06^{\circ}$ & $<1$ & $<1$ \\
\hline & P. aeruginosa ATCC 9027 & $6.0^{a}$ & $5.32 \pm 0.04^{a}$ & $2.98 \pm 0.14^{b}$ & $1.77 \pm 0.05^{\circ}$ & $<1$ & $<1$ \\
\hline \multirow{3}{*}{6} & E. coli ATCC 8739 & $5.4^{a}$ & $2.29 \pm 0.06^{b}$ & $1.27 \pm 0.04^{\circ}$ & $<1$ & $<1$ & $<1$ \\
\hline & S. Enterica ATCC 43972 & $5.9^{a}$ & $2.54 \pm 0.11^{b}$ & $1.43 \pm 0.09^{\circ}$ & $<1$ & $<1$ & $<1$ \\
\hline & P. aeruginosa ATCC 9027 & $6.0^{a}$ & $4.55 \pm 0.04^{\mathrm{a}}$ & $3.12 \pm 0.14^{b}$ & $1.67 \pm 0.13^{\circ}$ & $<1$ & $<1$ \\
\hline \multirow{3}{*}{7} & E. coli ATCC 8739 & $5.4^{\mathrm{a}}$ & $3.77 \pm 0.06^{b}$ & $1.92 \pm 0.08^{\circ}$ & $<1$ & $<1$ & $<1$ \\
\hline & S. Enterica ATCC 43972 & $5.9^{\mathrm{a}}$ & $4.15 \pm 0.04^{b}$ & $2.44 \pm 0.06^{\circ}$ & $1.84 \pm 0.03^{\circ}$ & $<1$ & $<1$ \\
\hline & P. aeruginosa ATCC 9027 & $6.0^{a}$ & $5.20 \pm 0.05^{a}$ & $4.56 \pm 0.09^{b}$ & $2.66 \pm 0.1^{\circ}$ & $1.69 \pm 0.09^{\circ}$ & $<1$ \\
\hline \multirow{3}{*}{8} & E. coli ATCC 8739 & $5.4^{a}$ & $1.44 \pm 0.04^{b}$ & $<1$ & $<1$ & $<1$ & $<1$ \\
\hline & S. Enterica ATCC 43972 & $5.9^{a}$ & $1.58 \pm 0.1^{b}$ & $<1$ & $<1$ & $<1$ & $<1$ \\
\hline & P. aeruginosa ATCC 9027 & $6.0^{\mathrm{a}}$ & $4.67 \pm 0.05^{a}$ & $3.66 \pm 0.09^{b}$ & $1.33 \pm 0.02^{\circ}$ & $<1$ & $<1$ \\
\hline \multirow{3}{*}{9} & E. coli ATCC 8739 & $5.4^{a}$ & $2.71 \pm 0.08^{b}$ & $1.92 \pm 0.05^{\circ}$ & $<1$ & $<1$ & $<1$ \\
\hline & S. Enterica ATCC 43972 & $5.9^{a}$ & $3.05 \pm 0.09^{b}$ & $2.12 \pm 0.11^{\circ}$ & $1.18 \pm 0.1^{\circ}$ & $<1$ & $<1$ \\
\hline & P. aeruginosa ATCC 9027 & $6.0^{\mathrm{a}}$ & $5.0 \pm 0.04^{a}$ & $4.27 \pm 0.08^{b}$ & $3.64 \pm 0.05^{b}$ & $1.61 \pm 0.09^{\circ}$ & $<1$ \\
\hline \multirow{3}{*}{10} & E. coli ATCC 8739 & $5.4^{a}$ & $<1$ & $<1$ & $<1$ & $<1$ & $<1$ \\
\hline & S. Enterica ATCC 43972 & $5.9^{a}$ & $<1$ & $<1$ & $<1$ & $<1$ & $<1$ \\
\hline & P. aeruginosa ATCC 9027 & $6.0^{a}$ & $<1$ & $<1$ & $<1$ & $<1$ & $<1$ \\
\hline \multirow{3}{*}{11} & E. coli ATCC 8739 & $5.4^{\mathrm{a}}$ & $2.21 \pm 0.07^{b}$ & $<1$ & $<1$ & $<1$ & $<1$ \\
\hline & S. Enterica ATCC 43972 & $5.9^{a}$ & $2.45 \pm 0.09^{b}$ & $1.13 \pm 0.1^{b}$ & $<1$ & $<1$ & $<1$ \\
\hline & P. aeruginosa ATCC 9027 & $6.0^{a}$ & $3.00 \pm 0.07^{b}$ & $1.54 \pm 0.04^{\circ}$ & $<1$ & $<1$ & $<1$ \\
\hline
\end{tabular}

$\pm:$ Standard deviation of three replicates

a-c: Averages with different letters in the same column are significantly different $(P<0.05)$. 
Interestingly, the MPB / $[\mathrm{Ml} / \mathrm{MCl}]$ blend was the best combination that inhibited the growth of this microorganism. In fact, it led to the elimination of the microbial load from the third $d$ of storage.

O'Neill and Mead (1982) studied the effect of different parabens on E. coli and P. aeruginosa. They reported that the initial kill rates of $E$. coli by methyl, ethyl and propyl parabens were similar at equal saturation fractions. Zedan and Serry (1984) demonstrated that $P$. aeruginosa was unable to grow on methyl paraben alone except after prolonged incubations ( $15 \mathrm{~d}$ or more) where selection of resistant cells occurred.

The initial population of $C$. albicans and $A$. brasiliensis was $6 \log _{10} \mathrm{CFU} / \mathrm{ml}$. This value decreased during the storage period in non-treated samples, and treated samples with different preservatives showed a significant decrease and elimination $(P<0.05)$ of the two microbial strains from the baby shampoo samples. Table 4 shows that parabens MPB, MAD and SHB and even the combination MPB / [MI/MCl] could eliminate C. albicans ATCC 10231 and A. brasiliensis ATCC 16404 only after $21 \mathrm{~d}$ of storage. However, parabens blend MPB / MD and SHB / MD could inhibit mould growth after $14 \mathrm{~d}$ of storage. Interestingly, $C$. albicans and A. brasiliensis were completely inhibited by the MPB / SHB combination at a final concentration of $1 \%$. On the other hand, the isothiazolinone-preservative formula [Ml/MCl] was not effective in eliminating C. albicans ATCC 10231 and A. brasiliensis ATCC 16404 from the inoculated samples. Finally, the best combination that eliminated the microbial strains was a parabens combination (SHB / MPB) followed by the combinations MD / MPB, MD / SHB and SHB / [Ml/MCl] that respectively showed an inhibition after 3 and $14 \mathrm{~d}$ of storage. (Table 4)

In accordance with our findings, Acott and Labuza (1975) reported that methyl- and propyl parabens inhibited growth of $A$. brasiliensis at 0.05 and $0.1 \%$ concentration during the period of storage for 9 months.

The study of the effect of different combinations of preservatives on the microbiological quality of baby shampoo showed that alone or in combination with isothiazolinone, parabens were able to reduce and in-

TABLE 4. Effect of preservatives on the microbial load of yeast and fungi: Candida albicans ATCC 10231, and Aspergillus brasiliensis ATCC 16404

\begin{tabular}{|c|c|c|c|c|c|c|c|}
\hline \multirow[t]{2}{*}{ Sample No. } & \multirow{2}{*}{$\begin{array}{l}\text { Microorganisms } \\
\text { (Yeast and fungal) }\end{array}$} & \multicolumn{6}{|c|}{ Microbial load $\left(\log _{10} \mathrm{CFU} / \mathrm{ml}\right)$} \\
\hline & & Initial & $3 d$ & $7 d$ & $14 d$ & $21 d$ & $28 d$ \\
\hline \multirow{2}{*}{1} & C. albicans ATCC 10231 & $6.0^{a}$ & $5.66 \pm 0.07^{\mathrm{a}}$ & $4.38 \pm 0.09^{b}$ & $3.89 \pm 0.05^{b}$ & $2.34 \pm 0.09^{\circ}$ & $1.69 \pm 0.04^{\circ}$ \\
\hline & A. brasiliensis ATCC 16404 & $6.0^{\mathrm{a}}$ & $5.59 \pm 0.06^{a}$ & $4.47 \pm 0.09^{b}$ & $3.91 \pm 0.08^{b}$ & $2.58 \pm 0.02^{\circ}$ & $1.53 \pm 0.07^{\circ}$ \\
\hline \multirow{2}{*}{2} & C. albicans ATCC 10231 & $6.0^{\mathrm{a}}$ & $4.92 \pm 0.09^{b}$ & $2.19 \pm 0.09^{\circ}$ & $1.22 \pm 0.03^{\circ}$ & $<1$ & $<1$ \\
\hline & A. brasiliensis ATCC 16404 & $6.0^{\mathrm{a}}$ & $5.0 \pm 0.07^{\mathrm{a}}$ & $2.48 \pm 0.09^{b}$ & $1.3 \pm 0.02^{c}$ & $<1$ & $<1$ \\
\hline \multirow{2}{*}{3} & C. albicans ATCC 10231 & $6.0^{\mathrm{a}}$ & $4.6 \pm 0.04^{b}$ & $3.42 \pm 0.1^{b}$ & $2.0 \pm 0.11^{\circ}$ & $<1$ & $<1$ \\
\hline & A. brasiliensis ATCC 16404 & $6.0^{a}$ & $4.69 \pm 0.09^{b}$ & $3.63 \pm 0.03^{b}$ & $2.13 \pm 0.07^{\circ}$ & $<1$ & $<1$ \\
\hline \multirow{2}{*}{4} & C. albicans ATCC 10231 & $6.0^{\mathrm{a}}$ & $5.20 \pm 0.04^{a}$ & $4.63 \pm 0.08^{b}$ & $2.08 \pm 0.05^{\circ}$ & $<1$ & $<1$ \\
\hline & A. brasiliensis ATCC 16404 & $6.0^{\mathrm{a}}$ & $4.92 \pm 0.09^{a}$ & $2.19 \pm 0.07^{b}$ & $1.22 \pm 0.04^{\circ}$ & $<1$ & $<1$ \\
\hline \multirow{2}{*}{5} & C. albicans ATCC 10231 & $6.0^{a}$ & $5.68 \pm 0.09^{a}$ & $4.56 \pm 0.1^{\mathrm{a}}$ & $4.0 \pm 0.7^{a}$ & $2.75 \pm 0.06^{b}$ & $1.52 \pm 0.09^{\circ}$ \\
\hline & A. brasiliensis ATCC 16404 & $6.0^{\mathrm{a}}$ & $5.71 \pm 0.04^{\mathrm{a}}$ & $4.78 \pm 0.06^{a}$ & $3.28 \pm 0.09^{b}$ & $2.13 \pm 0.06^{\circ}$ & $1.17 \pm 0.1^{\circ}$ \\
\hline \multirow{2}{*}{6} & C. albicans ATCC 10231 & $6.0^{a}$ & $3.4 \pm 0.07^{b}$ & $1.94 \pm 0.08^{\circ}$ & $<1$ & $<1$ & $<1$ \\
\hline & A. brasiliensis ATCC 16404 & $6.0^{a}$ & $3.6 \pm 0.06^{b}$ & $1.98 \pm 0.09^{\circ}$ & $<1$ & $<1$ & $<1$ \\
\hline \multirow{2}{*}{7} & C. albicans ATCC 10231 & $6.0^{a}$ & $4.92 \pm 0.05^{a}$ & $2.71 \pm 0.09^{b}$ & $<1$ & $<1$ & $<1$ \\
\hline & A. brasiliensis ATCC 16404 & $6.0^{a}$ & $4.12 \pm 0.04^{\mathrm{a}}$ & $2.99 \pm 0.09^{b}$ & $<1$ & $<1$ & $<1$ \\
\hline \multirow[t]{2}{*}{8} & C. albicans ATCC 10231 & $6.0^{a}$ & $4.23 \pm 0.03^{\mathrm{a}}$ & $3.11 \pm 0.1^{b}$ & $2.37 \pm 0.11^{b}$ & $1.07 \pm 0.04^{\circ}$ & $<1$ \\
\hline & A. brasiliensis ATCC 16404 & $6.0^{a}$ & $4.55 \pm 0.14^{\mathrm{a}}$ & $3.03 \pm 0.08^{b}$ & $2.0 \pm 0.09^{\circ}$ & $1.76 \pm 0.05^{\circ}$ & $<1$ \\
\hline \multirow{2}{*}{9} & C. albicans ATCC 10231 & $6.0^{\mathrm{a}}$ & $<1$ & $<1$ & $<1$ & $<1$ & $<1$ \\
\hline & A. brasiliensis ATCC 16404 & $6.0^{\mathrm{a}}$ & $<1$ & $<1$ & $<1$ & $<1$ & $<1$ \\
\hline \multirow{2}{*}{10} & C. albicans ATCC 10231 & $6.0^{\mathrm{a}}$ & $5.0 \pm 0.07^{\mathrm{a}}$ & $2.66 \pm 0.09^{b}$ & $1.67 \pm 0.07^{\circ}$ & $<1$ & $<1$ \\
\hline & A. brasiliensis ATCC 16404 & $6.0^{a}$ & $4.5 \pm 0.04^{a}$ & $3.92 \pm 0.08^{b}$ & $2.2 \pm 0.03^{\circ}$ & $<1$ & $<1$ \\
\hline \multirow{2}{*}{11} & C. albicans ATCC 10231 & $6.0^{a}$ & $3.89 \pm 0.09^{b}$ & $2.48 \pm 0.07^{b}$ & $<1$ & $<1$ & $<1$ \\
\hline & A. brasiliensis ATCC 16404 & $6.0^{a}$ & $3.8 \pm 0.06^{b}$ & $2.22 \pm 0.04^{b}$ & $<1$ & $<1$ & $<1$ \\
\hline
\end{tabular}

$\pm:$ Standard deviation of three replicates

a- c: Averages with different letters in the same column are significantly different $(P<0.05)$. 
hibit the bacterial growth, and these results are in accordance with those showed by Maddox (1982). In addition, combinations of parabens were shown to have a synergistic effect on bacteria as earlier described by Doron et al. (2001) and Ma and Marquis (1996). Furthermore, Soni et al. (2001) concluded that parabens were likely to have multiple targets and biological effects and could be used as antimicrobial preservatives, particularly in cosmetic products. Our findings are in agreement with those results.

$[\mathrm{Ml} / \mathrm{MCl}]$ has been used extensively for more than twenty years as an antimicrobial in cosmetics (e.g. skin creams and shampoos). [MI/MCl] has broadspectrum antimicrobial activity against Gram-positive bacteria, Gram-negative bacteria, yeasts and fungi, at very low concentrations and over a broad $\mathrm{pH}$ range (Law and al., 1984). Our study showed the effect of [Ml/MCl] against $M$. luteus and $S$. aureus (Gram positive bacteria), E. coli, $P$. aeruginosa and $S$. enterica (Gram negative bacteria) and fungi ( $A$. brasiliensis and C. albicans).

For the stability test at ambient conditions, all treated samples had the same characteristics as the non-treated one regarding foaming properties (data not shown). Consequently, the preservatives used do not affect the physical appearance of the baby shampoo.

The $\mathrm{pH}$ of shampoos has been shown to be important for improving the hair quality and minimizing eye irritation. The current trend to promote shampoos of lower $\mathrm{pH}$ is one of the ways to minimize damage to the hair. Mild acidity prevents swelling and promotes tightening of the scales, thereby inducing shine. All the shampoos were acid balanced and in the range from 5.5 to 5.9 , which is near to the skin pH (data not shown). All the eleven formulations of shampoo showed similar foaming characteristics in distilled wa-

TABLE 5. Foam retention of baby shampoo formulations with preservatives

\begin{tabular}{cccccc}
\hline Sample No & \multicolumn{5}{c}{ Time (min) } \\
& 1 & 2 & 3 & 4 & 5 \\
\hline 1 & 165.3 & 163.3 & 162.0 & 161.4 & 159.3 \\
2 & 155.2 & 154.2 & 152.3 & 150.8 & 148.2 \\
3 & 140.1 & 136.8 & 134.4 & 132.5 & 130.2 \\
4 & 143.9 & 142.5 & 141.3 & 140.2 & 139.7 \\
5 & 156.8 & 155.0 & 150.5 & 146.4 & 143.0 \\
6 & 160.9 & 156.9 & 153.7 & 154.2 & 155.9 \\
7 & 179.4 & 177.7 & 176.3 & 175.5 & 173.5 \\
8 & 170.0 & 169.3 & 168.7 & 166.4 & 164.4 \\
9 & 180.9 & 179.1 & 178.0 & 176.5 & 175.5 \\
10 & 185.6 & 184.3 & 182.3 & 180.0 & 179.6 \\
11 & 188.7 & 186.6 & 184.0 & 182.2 & 180.0 \\
\hline
\end{tabular}

ter. All samples had significantly comparable foaming properties (Table 5). Therefore, the preservatives used did not affect the foam stability of the baby shampoo. Stability and acceptability of organoleptic properties (odor and color) of formulations during the storage period indicated that they were chemically and physically stable (data not shown).

\section{ACKNOWLEDGMENTS}

This research was funded by the Tunisian Ministry of Higher Education, Scientific Research and Technology. The authors wish to express their gratitude to "Parfumerie Africa" for the baby shampoo used in the study.

\section{REFERENCES}

Acott, K.M., and Labuza, T.P. (1975) Inhibition of Aspergillus niger in an intermediate moisture food system. J. Food Sci., 40, 137-139.

Aghel, N., Moghimipour, B., and Dana, R.A. (2007) Formulation of a herbal shampoo using total aponins of acanthophyllum squarrosum. Iranian J. Pharm. Res., 6, 167-172.

Barel, A.O., Paye, M., and Maibach, H.I. (2001) Handbook of Cosmetic Science and Technology, pp. 423, 583-588, 773-775, Informa Healthcare, New York.

Becks, V., and Lorenzoni, N. (1995) Pseudomonas aeruginosa outbreak in a neonatal intensive care unit: a possible link to contaminated hand lotion. Am. J. Infect. Control., 23, 396-398.

Behravan, J., Bazzaz, F., and Malaekeh, P. (2005) Survey of bacteriological contamination of cosmetic creams in Iran. Int. J. Dermatol., 44, 482-485.

Chapman, D.G. (1987) Preservatives available for use. In Society for Applied Bacteriology Technical Series 22: Preservatives in the Food, Pharmaceutical and Environmental Industries (Board, R.G., Allwood, M.C., and Banks, J.G., Eds.), Blackwell Scientific, Bedford, U.K.

Collier, P.J., Ramsey, A., Waigh, R.D., Douglas, K.T., Austin, P., and Gilbert, P. (1990) Chemical reactivity of some isothiazolinone biocides. J. Appl. Microbiol., 69, 578.

Cowen, R.A., and Steiger, B. (1976) Antimicrobial activity: a critical review of test methods of preservative efficacy. J. Soc. Cosmet. Chem., 27, 467.

Doron, S., Friedman, M., Falach, M., Sadovnic, E., and Zvia, H. (2001) Antibacterial effect of parabens against planktonic and biofilm Streptococcus sobrinus. Int. J. Antimicrob. Ag., 18, 575-578.

Durant, C., and Higdon, P. (1991) Methods for assessing antimicrobial activity. In Society for Applied Bacteriology Technical Series 27: Mechanisms of Action of Chemical Biocides (Denyer, S.P. and Hugo, W.B., Eds.), Blackwell Scientific, Bedford, U.K.

FDA (Food and Drug Administration). (2001) Bacteriological analytical manual. ( $8^{\text {th }}$ ed), Washington, D.C.

Fox, C. (1988) Introduction to the Formulation of Shampoos. Cosmet Toilet., 103, 25-58.

Geis, P.A. (2006) Cosmetic microbiology: Apractical approach (Second Edition), pp. 111-146, Taylor and 
Francis Group, New York.

ISO/WD 11930. (2008) Evaluation of the antimicrobial protection of a cosmetic product.

Jacobs, G.P., and Sade, N. (1984) Hypoxic radiosensitization by the antimicrobial methyl paraben. Int. J. Radiat. Oncol, Biol. Physiol., 10, 1217-1220.

Klein, K. (2004) Evaluating Foam. Cosmetics and Toiletries Magazine., 119, 32-35.

Law, A.B., Moss, J.N., and Lashen, E.S. (1984) Kathon CG: a new single component, broad spectrum preservative for cosmetics and toiletries. In Cosmetic and Drug Preservation: Principles and Practice (Karaba, J.J., ed.), pp. 129-141, Marxel Decker, New York.

Ma, Y., and Marquis, R.E. (1996) Irreversible paraben inhibition of glycolysis by Streptococcus mutans GS-5. Lett. Appl. Microbiol., 23, 329-333.

Maddox, D.N. (1982) The role of $p$-hydoxybensoates in modern cosmetics. Cosmet. Toilet., 97, 85-88.

Mainkar, A.R., and Jolly C.I. (2000) Evaluation of commercial herbal shampoos. Int. J Cosmet. Sci., 22, 385-391.
O'Neill, J.J., and Mead, C.A. (1982) The parabens: bacterial adaptation and preservative capacity. J. Soc. Cosmet. Chem., 33, 75-84.

Ravita, T.D., Tanner, R.S., Ahearn, D.G., Arms, E.L., and Crockett, P.W. (2009) Post-consumer use efficacies of preservatives in personal care and topical drug products: relationships to preservative category. J. Ind. Microbiol. Biot., 36, 35-38.

Russell, A.D. (2003) Challenge testing: principles and practice. Int. J. Cosmet. Sci., 25, 147-153.

SAS. (1990) SAS/STAT user's guide. Cary, NC, USA: Statistical Analysis System Institute, Inc.

Soni, M.G., Burdock, G.A., Taylor, S.L., and Greenberg, N.A. (2001) Safety assessment of propylparaben. Food Chem. Toxicol., 39, 513-532.

USP: United States Pharmacopeia. (1994) Antimicrobial preservatives efficacy, (Rockwell, MD), p. 1681.

Zedan, H.H., and Serry, F.M. (1984) Metabolism of esters of p-hydroxybenzoic acid by a strain of Pseudomonas aeruginosa. Egypt J. Microbiol., 19, 41-54. 